\title{
BMJ Open Mixed methods study protocol to explore acculturation, lifestyles and health of immigrants from the Community of Portuguese-Speaking Countries in two Iberian contexts: how to face uncertainties amidst the COVID-19 pandemic
}

\author{
Daniela Alves, ${ }^{1,2}$ Isabel Craveiro, ${ }^{1,2}$ Nekane Basabe, ${ }^{3}$ Luzia Gonçalves (i) ${ }^{1,2,4}$
}

To cite: Alves D, Craveiro I, Basabe N, et al. Mixed methods study protocol to explore acculturation, lifestyles and health of immigrants from the Community of PortugueseSpeaking Countries in two Iberian contexts: how to face uncertainties amidst the COVID-19 pandemic. BMJ Open 2021;11:e048818. doi:10.1136/ bmjopen-2021-048818

- Prepublication history for this paper is available online. To view these files, please visit the journal online (http://dx.doi. org/10.1136/bmjopen-2021048818).

Received 07 January 2021 Accepted 18 June 2021

Check for updates

(C) Author(s) (or their employer(s)) 2021. Re-use permitted under CC BY-NC. No commercial re-use. See rights and permissions. Published by BMJ.

For numbered affiliations see end of article.

Correspondence to Luzia Gonçalves;

LuziaG@ihmt.unl.pt

\section{ABSTRACT}

Introduction Studies which focus on the process of acculturation in the lifestyles, nutritional status and health of immigrants from the Community of PortugueseSpeaking Countries (CPLP) in the Iberian Peninsula are still scarce. This study aims to explore the influence of the acculturation process and dietary acculturation on the lifestyle and nutritional and health status of CPLP immigrants in Portugal and Spain, focusing on two Iberian contexts: Lisbon Metropolitan Area and the Basque Country.

Methods and analysis A mixed methods sequential explanatory design, combining cross-sectional studies and semistructured interviews. Official data will also be analysed. Primary data will be collected through a questionnaire and assessment of nutritional status and body composition. The estimated samples sizes are 1061 adults ( $\geq 18$ years old) in the Lisbon Metropolitan Area and 573 in the Basque Country. Time-location sampling will be used for the quantitative component and non-probabilistic sampling for the qualitative component. If safety conditions are not guaranteed due to the COVID-19 pandemic, online studies will be conducted. The semistructured interviews will complement the questionnaire data and extend knowledge about the process of acculturation of CPLP immigrants and their relationship with eating habits and physical activity. Thematic analysis will be used for qualitative data. Triangulation of data derived from different methods will be carried out. An integrative approach will be used to address potential discrepancies in findings and limitations inherent to the study design. As inter-method discrepancies may occur, triangulation protocol will be used, elaborating a 'convergence coding matrix' to display findings emerging from each component of the study.

Ethics and dissemination Ethical approval was obtained through the IHMT Ethics Council (Doc No 20/2020), Portugal, and it was submitted to the Ethics Committee of the UPV/EHU (Doc No under revision), Spain.
Strengths and limitations of this study

This research will use mixed methods to obtain quality data to deepen the knowledge of the phenomenon of acculturation and its relationship with the lifestyles, nutritional and health status of Community of Portuguese-Speaking Countries (CPLP) immigrants in the two Iberian contexts, providing indicators for an adequate response to their health needs.

- To better understand if the language of the host country can favour the process of acculturation and, consequently, the lifestyle and health of CPLP immigrants.

- In current COVID-19 pandemic context, assessment of body composition by a nutritionist can be compromised.

- Samples may not be representative of the entire migrant population from all CPLP countries in both contexts.

\section{INTRODUCTION}

'Good Health and Well-Being' is one of the Agenda 2030 Sustainable Development Goals and migration is crucial for meeting this agenda. ${ }^{1-4}$ Migration is the movement of people from their usual residence to another place, within a country or state or across international borders to another country, region, or continent, according, according to the definition of International Organization to Migration. ${ }^{5}$ The same source defines an immigrant from the perspective of the country of arrival, a person who moves into a country other than that of his or her nationality or usual residence, so that the country of destination effectively becomes his or her new country of usual residence. ${ }^{5}$ Migration 
has increased in recent decades in Europe. ${ }^{67}$ According to the United Nations, roughly 82 million migrants lived in Europe in 2019. ${ }^{7}$

Migrants play an important role in population growth, counteracting population ageing and making an essential contribution to the sustainability and economic development of their arrival countries. ${ }^{89}$ On the other hand, they are considered a vulnerable population group in terms of physical, mental and social health. ${ }^{6}{ }^{10-13}$ Thus, public health policies of the host countries must pay particular attention to the health of immigrants. ${ }^{3}$

The concept of acculturation, associated with migration, is a process by which a group, usually a minority, learns and/or adopts cultural patterns (values, norms, ideas, behaviours) from a dominant group, ${ }^{14-18}$ which may result in the genesis of a new culture that brings together elements from the two original cultures. ${ }^{14-19}$ Berry ${ }^{19}$ defined four acculturation strategies: (1) separation (high affiliation to the original culture, low affiliation to the new culture); (2) assimilation (high affiliation to the new culture, low affiliation to the original culture); (3) integration (high affiliation to both cultures); and (4) marginalisation (low affiliation to cultures).

Dietary acculturation is the process by which immigrants adopt the dietary practices of the host country. ${ }^{201}$ Satia ${ }^{2021}$ mentions some factors that influence the process of dietary acculturation such as: age, gender, education, professional situation, language, the composition and size of the household, number of children, income, place of residence, access to foods, access to traditional supermarkets, beliefs regarding diet and health, social integration, exposure to the culture of the host country and level of nutritional transition in the country of origin.

Regarding the influence of sociodemographic and economic factors in the process of acculturation, in general, women reveal more difficulties in the adaptation process to the host country, especially when origin and destination cultures are very different. ${ }^{22-24}$ Adult or older people have greater difficulties in adapting to the host country. ${ }^{22-25}$ Immigrants with higher education and income have higher acculturation levels. ${ }^{22-25}$ Language proficiency and cultural proximity are also associated with higher acculturation levels. ${ }^{23-26}$ Acculturation process and dietary acculturation are associated with lifestyle and nutritional status, and consequently, with the health of migrants. ${ }^{10115}$ Some findings in the literature on this topic are controversial, describing both positive and negative impacts on the health of immigrants. ${ }^{30}$ 27-34

The Community of Portuguese-Speaking Countries (CPLP) includes nine countries: Angola, Brazil, Cabo Verde, Guinea-Bissau, Equatorial Guinea, Mozambique, Portugal, São Tomé and Príncipe, and Timor-Leste. ${ }^{35}$ Its population totals more than 291 million inhabitants ${ }^{3637}$ and occupies a total area of $10742000 \mathrm{~km}^{2}$ spread over the four continents $\left(7.2 \%\right.$ of the planet Earth). ${ }^{35}$ In addition to sharing the Portuguese language (in the majority of their countries), CPLP represents centuries of collective history, commercial, military, political and cultural exchanges, despite the enormous physical distance between geographical spaces and peoples. The Portuguese language is one of the most widespread languages in the world. ${ }^{38}$ It remains, today, a major language of international communication and has strong geographical projection, destined to increase. ${ }^{38}$ In terms of social integration, as mentioned above, the literature points out that cultural proximity and fluency in the language of the destination country, and the ability to learn it, increase the immigrant's success in the host country. ${ }^{26}{ }^{39-41}$ Thus, CPLP immigrants in Portugal may benefit from the process of acculturation.

Portugal and Spain are important destinations for CPLP immigrants. In Portugal in 2019, the foreign resident population totalled 590348 citizens (an increase of $22.9 \%$ compared with 2018 ). ${ }^{42}$ Seven out of 10 municipalities with the largest number of foreign citizens registered in Portugal belong to the Lisbon Metropolitan Area (LMA) (236113 citizens). ${ }^{42}$ In Spain, in the same year, the number of foreigners with a registration certificate or residence card was 5663348 . $^{43}$ In 2018, women of foreign nationality were responsible for $11 \%$ of births in Portugal $^{44}$ and $20.8 \%$ in Spain. ${ }^{45}$ These percentages are important because in 2018 the foreign population represented only $4.7 \%$ and $10.7 \%$ of the total population resident in Portugal and Spain, respectively. ${ }^{446}$

Portugal, which is part of the CPLP, due to its historical connections, is the host country for many immigrants from this community. ${ }^{47}$ As regards Spain, including the Basque Country (BC), the majority of foreign immigration is essentially from other countries in Europe, Latin America (including Brazil) and North Africa (mostly of Moroccan origin). ${ }^{49} 50$

To our knowledge, research studies about the relationship between acculturation and lifestyle, nutritional status and health of migrants in this community are still scarce. ${ }^{51}$ In addition, no studies were found about this topic comparing the two Iberian countries (Portugal and Spain). Regarding health indicators and nutritional status, in both countries, cardiovascular diseases were the main cause of death. ${ }^{5253}$

Approximately one-third of all deaths in Portugal and Spain are attributed to behavioural factors such as tobacco and alcohol consumption, dietary risks and low levels of physical activity. ${ }^{53}$ The prevalence of overweight and obesity in the Iberian Peninsula is over $60 \%{ }^{5455}$ Goulão et $a \tilde{l}^{1}$ assessed the nutritional status of CPLP immigrants in Portugal with percentages of overweight and obesity ranging from $35.1 \%$ to $50.8 \%$. Information about this immigrant community in Spain is even more scarce. A study carried out in Madrid with immigrants from Equatorial Guinea reports prevalence values of obesity of $11.0 \%$ in men and $23.2 \%$ in women. ${ }^{30}$ In the BC, overweight and obesity among immigrants from Latin America (including Brazilian participants) were over $34 \%$ and $6 \%$, respectively. ${ }^{56}$

Understanding the process of acculturation and dietary acculturation may be a step towards promoting the 
health of immigrant communities in the two European countries. ${ }^{57-59}$

\section{Objectives}

The main objective is to explore the influence of the acculturation process and dietary acculturation on the lifestyle and nutritional and health status of CPLP immigrants in Portugal and Spain, focusing on two Iberian contexts: LMA and the BC.

The specific objectives of the study are: (1) to understand the acculturation process and the dietary acculturation of the CPLP immigrants in LMA and BC; (2) to analyse the lifestyles (eating habits, physical activity and toxic habits) of CPLP immigrants in LMA and BC; (3) to characterise the health status and occurrence of chronic diseases among CPLP immigrants in LMA and $\mathrm{BC}$; (4) to understand the influence of acculturation strategies on overweight and obesity (using reported and measured data) and self-report of non-communicable chronic diseases in LMA and BC; (5) to understand differences and similarities in lifestyles, nutritional and health status among immigrants from different countries of the CPLP, analysing differences by sex; (6) to compare acculturation strategies, lifestyles, nutritional and health status between CPLP immigrants who live and/or work in LMA and CPLP immigrants who do not live and/or work in LMA; (7) to explore potential changes in lifestyle and body weight reported by immigrants in the confinement period during the COVID-19 pandemic; and (8) to promote integrated results that enhance the knowledge of CPLP immigrants in the two Iberian contexts, with a focus on lifestyles, nutritional status and health according to the experienced acculturation process.

\section{METHODS \\ Design}

This research will use a quantitative-qualitative design through cross-sectional and semistructured interview studies using a mixed methodology approach. ${ }^{60}$ The global study will be carried out in three phases: (1) application of a questionnaire; (2) body composition measurements, assessment of nutritional status and counselling by a nutritionist; and (3) conducting semistructured interviews (figure 1). The study of body composition will only be carried out if all safety conditions are ensured due to the COVID-19 pandemic. However, reported weight and height data will be collected during the questionnaire.

The data collection will be carried out in November and December 2020 in LMA and during 2021 in BC.

\section{Study locations}

The study will be carried out in LMA, Portugal and BC, Spain. LMA is located on the coast of Portugal that includes 18 municipalities in two districts (nine in the Lisbon district and nine in the Setúbal district) with more than 2.8 million inhabitants. ${ }^{61}$ The official language is Portuguese. BC is located in the northeast of Spain, with around 2.1 million inhabitants, ${ }^{62}$ composed of three provinces: Álava, Guipúzcoa and Bizkaia. BC has two official languages: Spanish and Euskera.

Population: Adult Immigrants from CPLP countries (1st or 2nd generation) living in Portugal and Spain: focus on Lisbon Metropolitan Area and Basque Country

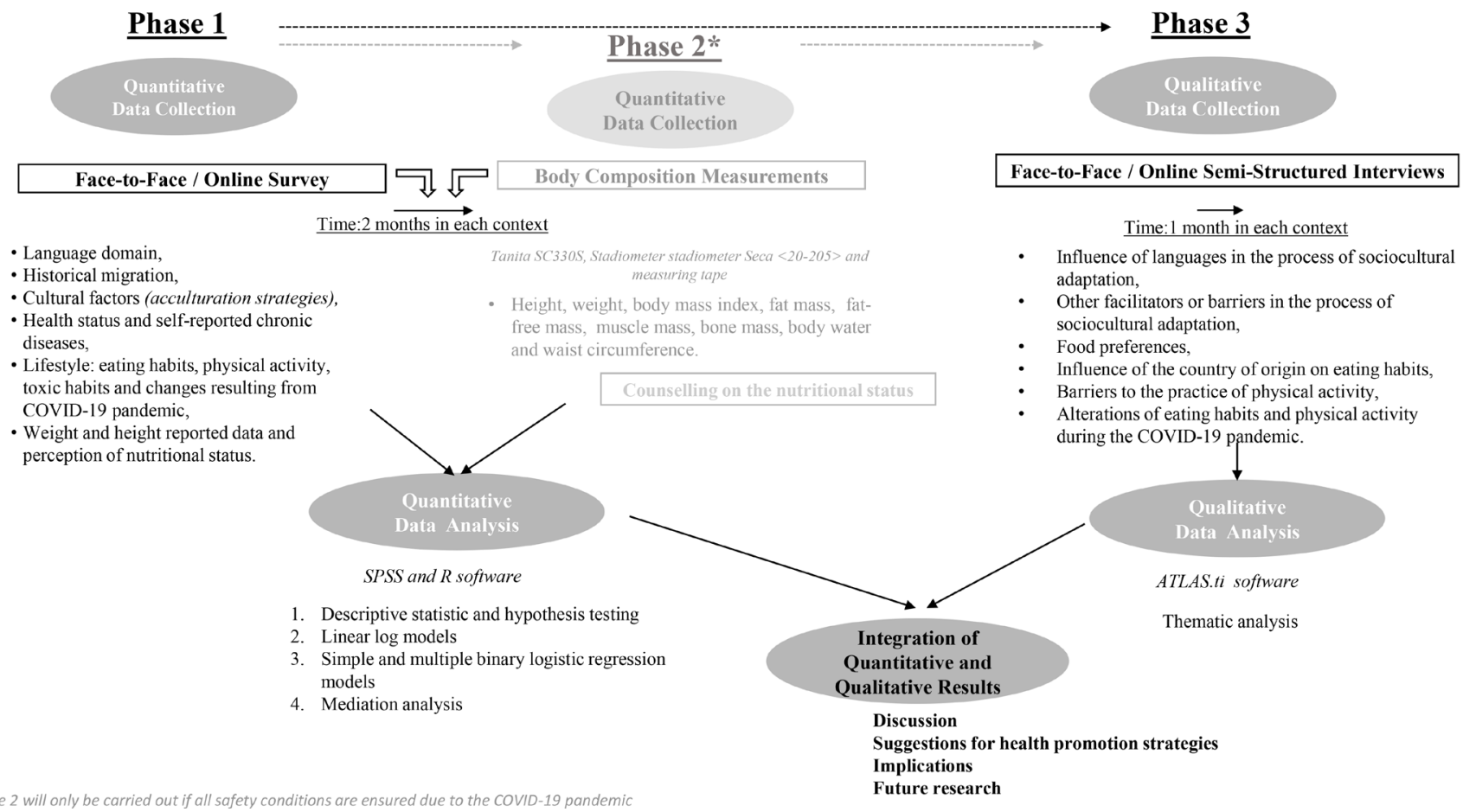

Figure 1 Study design. CPLP, Community of Portuguese-Speaking Countries. 


\section{Population}

Adult immigrants from first and/or second generation whose country of origin is part of CPLP and who have currently been living in LMA or BC for at least 6 months. Regarding the foreign population, according to the Portuguese Foreigners and Borders Service, 112850 and 30420 immigrants from the CPLP countries, respectively, lived in the district of Lisbon and Setúbal in 2019. ${ }^{42}$ Brazil and Cabo Verde are the most represented countries. In 2019, official data from the Basque Immigration Observatory indicate 16025 citizens from CPLP in $\mathrm{BC} .{ }^{46}$ The Portuguese and Brazilian population residing in the $\mathrm{BC}$ was the most represented of the CPLP countries in the same year. ${ }^{50}$

\section{Phase 1: quantitative methods/cross-sectional studies} Participants

The inclusion criteria for the participants in the crosssectional studies are: adult ( $\geq 18$ years) immigrants from first or second generation whose origin is a CPLP country, who can communicate in Portuguese or, in the case of the BC study, can communicate in Portuguese or Spanish and who have been living for at least 6 months in one of the two Iberian contexts. An immigrant is considered to be first generation if born in the country of origin and a second generation immigrant if born in the host country, but one or both parents were born in the country of origin. $^{32}$

\section{Sample size}

The prevalence of overweight (preobesity and obesity) found in previous studies ${ }^{305156}$ was considered to calculate the sample size in each context. Assuming that there will be no substantial differences between countries, and considering the estimate that provides a maximum size $(p=0.50)$ for a $95 \%$ CI to a proportion with a margin error of 3\%, the sample in LMA should have about 1061 participants (corrected for a population of 143270 CPLP immigrants in the district of Lisbon and Setúbal). In BC, with a margin error of $4 \%$, the estimated sample size is around 580 participants (for a population of 16025 CPLP immigrants in $\mathrm{BC}$ ).

Sampling frames will be sought from government and private entities to use random sampling methods. ${ }^{63-66} \mathrm{In}$ case of failure of lists from institutions/organisations, time-location sampling (TLS) will be used. ${ }^{65-67}$ This sampling method has been developed for hard-to-reach populations such as migrants. ${ }^{65-70}$ In TLS, the assumption is that it is possible to access the target population in predefined venues and encounters through random sampling of these venues and at different time units (eg, Venue A: Monday, 09:00-18:00; Venue D: Friday, 14:0017:00, etc). ${ }^{65-70}$ These venues may be public or private (recreational associations, public service centres, shopping centres, parks, bars, restaurants, cultural events, etc). In each context, a previous ethnographic mapping of the universe of these locations will be made. ${ }^{6671}$ Some authorisations will be needed for data collection.
The first participant and the following are chosen randomly from the previously determined time intervals, considering the duration of the questionnaire, the body composition assessment and counselling on nutritional status.

\section{Online study}

If it is impossible to collect face-to-face data, due to the COVID-19 pandemic, online surveys will be conducted. Despite the limitations of prefilled online questionnaires ${ }^{72}$ the literature described this strategy as valid and effective for the collection of public health data in the context of a pandemic. ${ }^{73-75}$ It will be possible to access the target population for data collection in a short time, with savings on $\operatorname{costs}^{72-75}$ and complying with the necessary security rules (social distancing). ${ }^{76}$ Associations of immigrants from CPLP or of another type but who work with this population in both contexts will be contacted to disseminate the questionnaire. They will be contacted by email and/or social media pages to present the project and requested to disclose the questionnaire. To increase the response rate, the principal investigator will disclose the study in groups and social media pages (Facebook, Instagram and LinkedIn) that have some connection and/or carry out work with the migrant population from CPLP. The questionnaire will be available for 2 months in each context.

\section{Questionnaire}

The questionnaire will be based on existing health questionnaires such as the National Health Survey of Portugal, ${ }^{77}$ the Basque Country Health Survey $^{78}$ and acculturation measures used in other studies. ${ }^{16} 19327980$ In LMA, the questionnaire will be done in Portuguese. In $\mathrm{BC}$, the option of choosing the language (Spanish or Portuguese) will be given for the questionnaire and the interview.

Seven themes will be included in the questionnaire: (1) spoken and written Portuguese/Spanish language; (2) sociodemographic data; (3) migration (years in the host country and other countries previously); (4) cultural factors (attitude and behaviour acculturation scales ${ }^{79} 80$ and sociocultural adaptation scale $\left.{ }^{80}\right)$; (5) health status; (6) lifestyle variables that include issues related to eating habits, level of dietary acculturation, ${ }^{81}$ physical activity, consumption of alcohol and tobacco and changes resulting from the COVID-19 pandemic); and (7) selfreported anthropometric data (weight and height) and perception of nutritional status. The study phase 1 outcomes are summarised in table 1 .

\section{Acculturation measures}

Accumulation will be measured considering two scales: (1) attitudes of acculturation and (2) behaviours of acculturation regarding the country of origin and the host county proposed by Basabe $e t a l .{ }^{79}$ Scales include six items with a Likert-type response ranging from 1 (Nothing) to 5 (Very). Combining these two scales, four acculturation 
Table 1 Variables and outcomes

Migration history: country of birth, parents' countries of birth, number of years in host country, generation status, reasons for immigration.

Prevalence of integrated, separated, assimilated and marginalised participants.

Prevalence of self-reported chronic disease

Lifestyle: quality of diet and variety of food,

Phase 1 prevalence of smokers and consumers of alcoholic beverages, physical activity and sedentary levels

Prevalence of overweight and obesity (reported data)

Effect of the acculturation strategy adopted on lifestyle and health

Lifestyle changes during the COVID-19 pandemic

Prevalence of overweight and obesity (measured data)

Phase 2

Prevalence of cardio-metabolic risk (low, moderate and high)

Language domain

Difficulty or ease in the process of adapting to the host country

Food preferences

Phase 3 Influence of the country of origin on eating habits

Barriers and challenges to the practice of physical activity

Changes in eating habits during the COVID-19 pandemic

strategies will be defined according to Basabe et al. ${ }^{79} \mathrm{~A}$ complementary approach to assess the acculturation level will be based on a score adapted from Alkerwi et $a l .{ }^{32}$ The sum of the three indicators (generation, spoken language and years of immigration) results in an acculturation level, ranging from 1 (less acculturated) to 4 (more acculturated).

Dietary acculturation is based on a scale ranging from 1 to 10 considering the fowling question: 'How similar are your eating habits here and those you had in your host country or the country of origin of your parents or closest family members?' The value 1 indicates that the participant has eating habits completely different from his country of origin (first generation) or the country of origin of his parents (second generation). The value 10 indicates the same eating habits. A low change in eating habits is considered if the scores vary between 7 and 10, a moderate change in eating habits for scores of 5 or 6 and a high change in eating habits for scores between 1 and $4 .^{81}$ In the qualitative component, these and other aspects of the acculturation process will be addressed through complementary and integrative ways, as described further.
Body composition

If the evolution of the COVID-19 pandemic is favourable, anthropometric measurements will be made by a nutritionist, after completing the questionnaire ${ }^{82}$ : height (stadiometer Seca 20-205 cm range), waist circumference (using a measuring tape), weight ( $\mathrm{kg}$ ), fat mass ( $\mathrm{kg}$ and $\%)$, fat-free mass $(\mathrm{kg})$, muscle mass $(\mathrm{kg})$, bone mass $(\mathrm{kg})$ and body water ( $\mathrm{kg}$ and \%) (Tanita SC330S with impedance) ${ }^{83}$ Derived indices will be calculated from the measured data (eg, body mass index, cardiovascular risk from the waist-height ratio and the nutritional status, according to the definition of the WHO). ${ }^{84-86}$

The nutritionist will provide information to the participant regarding their nutritional status and brief personalised advice for healthy eating and physical activity. In the case of obesity, the participant will be advised to seek out a nutritionist at the health centre of his residence for detailed monitoring, according to the ethical code for the nutritionist profession in Portugal and Spain. ${ }^{87} 88$

\section{Secondary data}

In each Iberian context, access to official data related to the target population will be requested, with the aim of making a more detailed and comparative analysis within the scope of this study. In Portugal, data will be requested from the following sources: (1) Portuguese National Health Questionnaire, carried out in 2014 and 2019, from the National Statistics Institute, and (2) National Health Survey with Physical Examination, carried out in 2015, from the Instituto Nacional Ricardo Jorge. In BC, information from the Basque Country Health Survey carried out in 2018 will be requested from the health department of the Basque government. The data requested will be sociodemographic characteristics, health status (chronic diseases), health determinants (eating habits, physical activity, consumption of tobacco and alcoholic beverages) and reported nutritional status. In the Portuguese context, information from measured anthropometric data (weight, height and waist and hip circumference) will be requested.

\section{Statistical analysis}

The data will be analysed with SPSS V.25.0 and R package. In the first phase, an exploratory and descriptive analysis will be carried out. The second phase will include parametric and non-parametric tests and multivariate analysis with different approaches such as linear log models ${ }^{89-92}$ to study the interaction between qualitative variables and simple and multiple binary logistic regression models ${ }^{93-95}$ to identify variables that are associated with a binary outcome. Mediation analyses will be carried out to ascertain whether the relationship between an independent variable and a dependent variable is mediated by a third variable. ${ }^{96}$ In all analyses performed, statistical assumptions and possible confounding variables will be considered. $^{97-99}$ 


\section{Phase 2/3: qualitative studies}

The qualitative component aims to complement the results of the cross-sectional studies and deepen knowledge about the process of acculturation and its relationship with lifestyle. It will also be an opportunity to understand how the COVID-19 pandemic affected eating habits and the practice of physical activity.

\section{Participants}

To participate in the qualitative study, a previous participation in cross-sectional studies is mandatory. In the cross-sectional studies, participants will declare their willingness (or not) to participate in later stages of this research, and will provide a contact (email and/or mobile phone). Other inclusion criteria will be defined after a preliminary analysis of the data obtained in crosssectional studies such as the level/strategy of acculturation and nutritional status.

\section{Sampling and data collection techniques}

Non-probabilistic sampling (convenience sampling) will be adopted from the participants who gave their contact during the questionnaire. Three attempts will be made to contact each participant and formal consent will be requested for participation in this stage. ${ }^{100}$

Semistructured interviews will be carried out ${ }^{101} 102$ by video call (eg, Skype, Zoom, WhatsApp, Messenger), if the participant prefers this option. Theoretical saturation sampling will be used to close the final sample size. ${ }^{100}$

A preliminary semistructured interview guide will be prepared with questions on three major themes: country of origin, acculturation and language, and lifestyles. Regarding the country of origin, second-generation immigrants will be asked about their parents' country of origin. Regarding acculturation and language, participants will be questioned about the influence (positive or negative) of the languages of the two contexts, as well as other facilitators or barriers encountered in the process of sociocultural adaptation. On the topic of lifestyles, questions will be asked about food preferences, influence of the country of origin and host country on eating habits, alterations of eating habits during the COVID-19 pandemic and barriers to the practice of physical activity (table 1 ). The interview topic guide will be finalised after the preliminary analysis of data from cross-sectional studies. All documents will be produced in Portuguese and translated into Spanish. In $\mathrm{BC}$, the participant may choose the language in which the interview will be conducted.

\section{Data analysis}

The interviews will be transcribed, and the data will be analysed using the content analysis technique. ${ }^{103} 104$ Thematic analysis will be carried out using phrases or paragraphs as units of analysis. ${ }^{103104}$ The units of analysis will be coded in alphanumeric form. ${ }^{100}{ }^{101}$ Content analysis will be carried out using the ATLAS.ti software. ${ }^{103105106}$ This software will be used to identify the themes emerging from the data, and this will provide a rich, detailed account of the data set. Themes will be compared by different members of the analysis team until a consensus is reached.

Patient and public involvement

No patient was involved.

\section{ETHICS AND DISSEMINATION}

The proposal was submitted and approved by the IHMT Ethics Council (Doc No 20/2020) and by the Ethics Committee of the University of the Basque Country (Doc No under revision). The documents/instruments will be produced in Portuguese and translated into Spanish.

Participants will be previously informed about the objectives and procedures of the study. Participation does not involve risks and no remuneration is foreseen. The confidentiality and anonymity of the participants will be guaranteed.

Informed consent will be requested in the various phases of the study. In the case of conducting the face-toface study, participants will give their written consent. In the online study, participants will give informed consent on the online platform of the survey.

Availability for participation in the qualitative study will be requested at the end of the survey and, in case of acceptance, there will be a survey field to collect a means of contact (email and/or phone number). This information will be unlinked and later deleted from the questionnaire database and inserted in a file protected with a password.

Regarding the informed consent of the qualitative component, the informed consent form will be previously sent to participants by email, allowing its contents to be read. Oral consent will be collected for all respondents, which will be recorded in the audio file.

The interviews will be transcribed by the doctoral student, providing for the omission or codification of elements that allow the identity of participants to be revealed. The ethical code of the profession of the nutritionist in Portugal and Spain will be fulfilled. ${ }^{87} 88$ All data and collected information will be saved with a password and will be destroyed after 5 years. We aim to disseminate the findings through national and international conferences, peer-reviewed journals and a doctoral thesis.

\section{DISCUSSION}

This study protocol uses a mixed methods approach to provide a better understanding about the process of acculturation and its relationship with lifestyles, nutritional and health status of CPLP immigrants in two Iberian contexts: the LMA-Portugal and the autonomous community of the BC-Spain. In both contexts, demographics and lifestyles are similar. However, the Portuguese language may help in the process of acculturation for CPLP immigrants in Portugal.

Based on a quantitative study, strategies and levels of acculturation and dietary acculturation will be defined using a questionnaire. The acculturation process will be 
deepened through a qualitative study in each context, exploring several themes of the interview guide, as how the language influenced (positively or negatively) the acculturation and other potential facilitators or barriers encountered in the sociocultural adaptation to host country. Regarding dietary acculturation, food preferences and the influence of the country of origin and host country on eating habits will be addressed in the qualitative studies. An integrative approach will be used to address several findings from quantitative and qualitative components, for a better understanding of the process of acculturation, including dietary acculturation, and the influence on health, nutritional status and lifestyle.

A possible risk of the study will be the impossibility of carrying out the assessment of body composition due to the pandemic situation. The analysis of the nutritional status measured as defined in the objectives may not be possible to maintain. However, reported weight and height data will be collected. Also reported data from secondary data sources that will be accessed, facilitating the discussion of the results of this study.

Limitations related to cross-sectional studies and the application of the questionnaire such as non-response, recall and social desirability bias will be considered. For the online study, several additional issues may amplify selection bias. Access to the internet may be a critical issue in some migrant communities. Even for those participants with good access to web platforms, the lack of a single internet registration, the possibility of a single internet user answering the questionnaire several times, opening date and closing date to the online survey, among others, bring difficulties to quantify the exact number of users reached, non-responses and also the characteristics of users who respond or do not respond. ${ }^{107} 108$ In general, this is a serious concern, but sometimes a bias due to non-response can be reduced by applying correction techniques such as adjustment weighting. ${ }^{109}$ On the other hand, immigrants are a hard-to-reach population, therefore an online study is a cheap and quick way to reach this population in safety conditions for COVID-19. TLS presents also well-established limitations. ${ }^{6670}$ Thus, generalisation of the findings may be compromised because it is difficult to obtain representative samples of the CPLP immigrants in both contexts.

The limitations of the qualitative component include, among others, prejudice and bias of the researcher, effects of observers and potential constraints on the replication of the study. There may be difficulties in transferring results from qualitative methods

Limitations derived from mixed methods will be the long time required for data collection and possible difficulty to integrate all results. ${ }^{110111}$ As intermethod discrepancies may occur, triangulation protocol will be used, ${ }^{112}$ elaborating a 'convergence coding matrix' to display findings emerging from each component of the study on the same page in order to assess eventual agreement, partial agreement, silence or dissonance between findings from different components. Silence means that a theme or finding arises from one data set and not another, and it might be expected because of the strengths of different methods to examine different aspects of the phenomenon. This might contribute to increase understanding or lead to further investigations. ${ }^{113}$

Despite the predicted limitations, sound scientific evidence will be produced that may contribute to the development of public health policies that promote a healthy lifestyle and better health results for these immigrants with specific characteristics and that still require further studies in the Iberian Peninsula.

\section{Author affiliations}

${ }^{1}$ Global Health and Tropical Medicine, Instituto de Higiene e Medicina Tropical, Universidade Nova de Lisboa, Lisboa, Portugal

${ }^{2}$ Unidade de Saúde Pública Internacional e Bioestatística, Instituto de Higiene e Medicina Tropical, Universidade Nova de Lisboa, Lisboa, Portugal

${ }^{3}$ Department of Social Psychology and Methodology of Behavioural Sciences,

Faculty of Pharmacy, Universidad del País Vasco, Vitoria, Spain

${ }^{4}$ Centro de Estatística e Aplicações da Universidade de Lisboa, Lisboa, Portugal

Contributors DA, IC, NB and LG designed the project. DA drafted the manuscript. IC, NB and LG drafted and revised the manuscript. All authors approved the final version.

Funding This study was funded by Fundação para a Ciência e Tecnologia (FCT) - Doctoral Grant SFRH/BD/115382/2016, UID/04413/2020, UIDB/0006/2020 and UIDP/0006/2020.

Competing interests None declared.

Patient and public involvement Patients and/or the public were involved in the design, or conduct, or reporting, or dissemination plans of this research. Refer to the Methods section for further details.

Patient consent for publication Not required.

Provenance and peer review Not commissioned; externally peer reviewed.

Open access This is an open access article distributed in accordance with the Creative Commons Attribution Non Commercial (CC BY-NC 4.0) license, which permits others to distribute, remix, adapt, build upon this work non-commercially, and license their derivative works on different terms, provided the original work is properly cited, appropriate credit is given, any changes made indicated, and the use is non-commercial. See: http://creativecommons.org/licenses/by-nc/4.0/.

ORCID iD

Luzia Gonçalves http://orcid.org/0000-0002-9710-1945

\section{REFERENCES}

1 Instituto Camões. Agenda 2030 - Objetivos de Desenvolvimento Sustentável. Available: http://www.instituto-camoes.pt/activity/oque-fazemos/cooperacao/cooperacao-portuguesa/mandato/ajudaao-desenvolvimento/agenda-2030 [Accessed 9 Jul 2018].

2 United Nations, Department of Economic and Social Affairs, Population Division. International migration report: highlights. New York: United Nations, 2017. https://www.un.org/development/desa/ publications/international-migration-report-2017.html

3 Wickramage K, Vearey J, Zwi AB, et al. Migration and health: a global public health research priority. BMC Public Health 2018;18:987.

4 Barragan E, Dhavan P, Fortier JP. Migration and Health in the Sustainable Development Goals. In: Migration in the 2030 Agenda. International Organization for Migration. Gervais Appave and Neha Sinha 2017:39-57.

5 International Organization for Migration. International Migration Law - Glossary on Migration. Geneva: International Organization for Migration, 2019.

6 Domnich A, Panatto D, Gasparini R. The "healthy immigrant" effect: does it exist in Europe today? Ital J Public Health 2012;9:e7532.

7 United Nations, Department of Economic and Social Affairs, Population Division. International migration 2019: highlights (ST/ ESA/SER. A/439). United Nations 2019. 
8 Gheasi M, Nijkamp P. A brief overview of international migration motives and impacts, with specific reference to Fdl. Economies 2017;5:31.

9 Riddle L. Diaspora Engagement and the Sustainable Development Goals. In: Migration in the 2030 agenda. International Organization for Migration, 2017. https://publications.iom.int/books/migration2030-agenda

10 Goulão B, Santos O, Carmo Ido. The impact of migration on body weight: a review. Cad Saude Publica 2015;31:229-45.

11 Derose KP, Escarce JJ, Lurie N. Immigrants and health care: sources of vulnerability. Health Aff 2007;26:1258-68.

12 Tran DT, Jorm L, Johnson M, et al. Effects of acculturation on lifestyle and health status among older Vietnam-born Australians. Asia Pac J Public Health 2015;27:NP2259-74.

13 Balidemaj A, Small M. The effects of ethnic identity and acculturation in mental health of immigrants: a literature review. Int $J$ Soc Psychiatry 2019;65:643-55.

14 International Organization for Migration. International Migration Law - Glossary on Migration [Internet]. Report No.: 25; 2011: 114 https://publications.iom.int/books/international-migration-lawndeg25-glossary-migration

15 Schwartz SJ, Unger J, eds. The Oxford handbook of acculturation and health. New York, NY: Oxford University Press, 468, 2017.

16 Berry JW. Conceptual approaches to acculturation. In: Chun KM, Balls Organista P, Marín G, eds. Acculturation: advances in theory, measurement, and applied research. Washington: American Psychological Association, 2003: 17-37Available. http://content. apa.org/books/10472-004

17 Redfield R, Linton R, Herskovits MJ. Memorandum for the study of Acculturation. Am Anthropol 1936;38:149-52.

18 Schumann M, Bug M, Kajikhina K, et al. The concept of acculturation in epidemiological research among migrant populations: a systematic review. SSM Popul Health 2020;10:100539.

19 Berry JW. Immigration, Acculturation, and adaptation. Appl Psychol 1997;46:5-34.

20 Satia JA. Dietary acculturation and the nutrition transition: an overview. Appl Physiol Nutr Metab 2010;35:219-23.

21 Satia JA. Dietary Acculturation: definition, process, assessment, and implications. Int J Hum Ecol 2003;4:71-86.

22 Bornstein $\mathrm{MH}$. The specificity principle in Acculturation science. Perspect Psychol Sci 2017;12:3-45.

23 Dow HD. The Acculturation processes: the strategies and factors affecting the degree of Acculturation. Home Health Care Manag Pract 2011;23:221-7

24 Berry JW. A psychology of immigration. J Soc Issues 2001:57:615-31.

25 Popovic-Lipovac A, Strasser B. A review on changes in food habits among immigrant women and implications for health. J Immigr Minor Health 2015;17:582-90.

26 Isphording IE, Otten S. Linguistic distance and the language fluency of immigrants. Ruhr economic papers. RWI - Leibniz-Institut für Wirtschaftsforschung, Ruhr-University Bochum, TU Dortmund University, University of Duisburg-Essen, 2011: 274.

27 Étémé G, Girard A, Massé J-C, et al. Do acculturation strategies have impacts on the self-declared health, well-being and lifestyle of first-generation allophone immigrants in Montreal, Canada? Int $J$ Migr Health Soc Care 2016;12:66-82.

28 Raza Q, Nicolaou M, Snijder MB, et al. Dietary acculturation among the South-Asian Surinamese population in the Netherlands: the HELIUS study. Public Health Nutr 2017;20:1983-92.

29 Martin-Fernandez J, Grillo F, Tichit C, et al. Overweight according to geographical origin and time spent in France: a cross sectional study in the Paris metropolitan area. BMC Public Health 2012;12:937.

30 Delisle HF, Vioque J, Gil A. Dietary patterns and quality in WestAfrican immigrants in Madrid. Nutr J 2009;8:3.

31 Delavari M, Sønderlund AL, Swinburn B, et al. Acculturation and obesity among migrant populations in high income countries--a systematic review. BMC Public Health 2013;13:458.

32 Alkerwi Ala'a, Sauvageot N, Pagny S, et al. Acculturation, immigration status and cardiovascular risk factors among Portuguese immigrants to Luxembourg: findings from ORISCAVLUX study. BMC Public Health 2012;12:864.

33 Casali ME, Borsari L, Marchesi I. Lifestyle and food habits changes after migration: a focus on immigrant women in Modena (Italy). Ann Ig Med Prev E Comunit2015;27:748-59.

34 Rodríguez Álvarez E, González-Rábago Y, Bacigalupe A, et al. Inmigración $Y$ salud: desigualdades entre La población autóctona $\mathrm{E}$ inmigrante en El País Vasco. Gac Sanit 2014;28:274-80.
35 CPLP - Comunidade dos Países de Língua Portuguesa. Available: https://www.cplp.org/ [Accessed 30 Sep 2018].

36 United Nations Population Fund. State of World Population 2019: unfinished business - the pursuit of rights and choices for all. United Nations, 2019.

37 ONU News. População dos países lusófonos. ONU News, 2019. Available: https://news.un.org/pt/story/2019/04/1667931 [Accessed 31 Aug 2020]

38 UNESCO. World Portuguese language day. UNESCO, 2020. Available: https://en.unesco.org/commemorations/portugueselanguage-day [Accessed 31 Aug 2020].

39 Basabe N, Bobowik M. Estatus grupal, discriminación, Y adaptación en inmigrantes latinoamericanos $Y$ africanos en España. Psicoperspectivas Individuo Soc 2013;12.

40 Adserà $A$, Pytliková $M$. The role of language in shaping international migration. Econ J 2015;125:F49-81.

41 Zlobina A, Basabe N, Páez D. Adaptación de Los inmigrantes extranjeros en España: superando El choque cultural. Migraciones. Publicación Del Instituto Universitario De Estudios Sobre Migraciones 2004;15:43-84.

42 Serviço de Estrangeiros e Fronteiras. Relatório de Imigração, Fronteiras E Asilo 2019. Oeiras, Portugal, 2020: 1-93.

43 Ministerio de Inclusión, Seguridad Social y Migraciones, Observatorio de la Inmigración. Extranjeros Residentes en España a 31 de Diciembre de 2019. Principales Resultados. Gobierno de España, 2020: 1-18.

44 Oliveira CR, Gomes N, Imigração EdeBda. Alto Comissariado para as Migrações (ACM, IP). Portugal: Lisboa, 2019.

45 Instituto Nacional de Estatística IP. Movimiento Natural de la Población (MNP) - Indicadores Demográficos Básicos (IDB. Instituto Nacional de Estadística, 2020.

46 Instituto Nacional de Estadística. Avance de la Estadística del Padrón Continuo a 1 de enero de 2019. INE-España, 2019. Available: https://www.ine.es/prensa/pad_2019_p.pdf

47 Baganha MI, Marques JC, Góis P. Imigrantes em Portugal: uma síntese histórica. Ler História 2009;56:123-33.

48 Padilla B, Ortiz A. Fluxos migratórios em Portugal: do boom migratório desaceleração no contexto de crise. Balanços e desafios. Rev Interdiscip Mobilidade Humana 2012.

49 Ministerio del Trabajo M e SS. Portal de Inmigración: Extranjeros Con certificado de registro $\mathrm{O}$ tarjeta de residencia en vigor. Principales resultados. portal de Inmigración, 2019. Available: http://extranjeros.mitramiss.gob.es/es/Estadisticas/operaciones/ con-certificado/index.html

50 Ikuspegi. Observatorio Vasco de Inmigración [Internet], 2019. Available: http://www.ikuspegi.eus/es/estadisticas/estadisticas.php [Accessed 20 Sep 2018].

51 Goulão B, Santos O, Alarcão V. Prevalência de excesso de peso NOS imigrantes brasileiros $\mathrm{E}$ africanos residentes em Portugal. Rev Port Cardiol 2015;33:24-32.

52 OCDE/Observatório Europeu dos Sistemas e Políticas de Saúde. State of health in the EU. Portugal perfil de saúde 2019. Brussels: Paris/Observatório Europeu DOS Sistemas E Políticas de Saúde and European Observatory on health systems and policies, 2019. Available: https://ec.europa.eu/health/state/country_profiles_en

53 OECD/European Observatory on Health Systems and Policies. State of Health in the EU. España: Perfil sanitario nacional 2019, [Internet]. Brussels: Paris/European Observatory on Health Systems and Policies, 2019. Available: https://ec.europa.eu/health/state/ country_profiles_en

54 Barreto M, Gaio V, Kislaya I. $1^{\circ}$ Inquérito Nacional de Saúde com Exame Físico (INSEF 2015): Estado de Saúde. Portugal: Lisboa, 2016.

55 Aranceta-Bartrina J, Pérez-Rodrigo C, Alberdi-Aresti G, et al. Prevalencia de obesidad General Y obesidad abdominal en La población adulta española (25-64 años) 2014-2015: estudio ENPE. Revista Española de Cardiología 2016;69:579-87.

56 Rodríguez E. Encuesta de salud a la población inmigrante en El País Vasco, 2009: población del Magreb, Senegal, Latinoamérica, China Y Pakistán residiendo en Bizkaia. Universidad del País Vasco/Euskal Erriko Unibertsitatea. Bilbao/IMISATE, 2011.

57 McDermott-Levy R. Acculturation: a concept analysis for immigrant health. Holist Nurs Pract 2009;23:282-8.

58 Patterson RE, Neuhouser ML, Satia JA. Dietary acculturation: applications to nutrition research and dietetics. J Am Diet Assoc 2002;102:1105-18

59 Cluskey MM. A Qualitative Study of the Dietary Acculturation among Long-term Hispanic Immigrants [Master Thesis]. [USA]: Oregon State University, 2013. Available: https://ir.library. oregonstate.edu/concern/graduate_thesis_or_dissertations/ hh63sz67q?locale=en 
60 Creswell JW, Creswell JD. Research design: qualitative, quantitative, and mixed methods approaches. 5th edn. Los Angeles: SAGE, 2018: 275 .

61 Instituto Nacional de Estatística. Área Metropolitana de Lisboa em números - 2018. Portugal, 2020. Available: https://www. ine.pt/xportal/xmain?xpid=INE\&xpgid=ine_publicacoes\& PUBLICACOESpub boui $=418948837 \&$ PUBLICACOESmodo $=2$

62 Eustat. Población de la C.A. de Euskadi por ámbitos territoriales, según razón entre los sexos, grupos de edad y nacionalidad - 2017, 2018. Available: http://www.eustat.eus/elementos/ele0011400/ Poblacion_de_la_CA_de_Euskadi_por_ambitos_territoriales segun_razon_entre_los_sexos_grupos_de_edad_y_nacionalidad/ tbl0011428_c.html [Accessed 20 Sep 2018].

63 Gonçalves L, de Oliveira MR, Pascoal C, et al. Sample size for estimating a binomial proportion: comparison of different methods. J Appl Stat 2012;39:2453-73.

64 Fosgate GT. Practical sample size calculations for surveillance and diagnostic investigations. J Vet Diagn Invest 2009;21:3-14.

65 Daniel J. Sampling essentials: practical guidelines for making sampling choices. Los Angeles: Sage Publications, 2012: 291.

66 Raymond HF, Ick T, Grasso M. Resource guide: time location sampling (TLS). 2A. San Francisco,Department of Public Health: Behavioral Survellance Unit, 2007.

67 Rechel B, Mladovsky P, Devillé W. Monitoring migrant health in Europe: a narrative review of data collection practices. Health Policy 2012;105:10-16.

68 Baio G, Blangiardo GC, Blangiardo M. Centre sampling technique in foreign migration surveys: a methodological note. J Off Stat 2011;27:451-65.

69 Karon JM, Wejnert C. Statistical methods for the analysis of timelocation sampling data. J Urban Health 2012;89:565-86.

70 Reichel D, Morales L. Surveying immigrants without sampling frames - evaluating the success of alternative field methods. Comp Migr Stud 2017:5:1.

71 Erickson M, Goldenberg SM, Master A, et al. Interpersonal and structural contexts of intimate partner violence among female sex workers in conflict-affected Northern Uganda. Women Health 2018;58:759-73.

72 Nayak M, Narayan KA. Strengths and weakness of online surveys. J Humanit Soc Sci 2019;24:31-8.

73 Geldsetzer P. Use of rapid online surveys to assess people's perceptions during infectious disease outbreaks: a cross-sectional survey on COVID-19. J Med Internet Res 2020;22:e18790.

74 Ali SH, Foreman J, Capasso A, et al. Social media as a recruitment platform for a nationwide online survey of COVID-19 knowledge, beliefs, and practices in the United States: methodology and feasibility analysis. BMC Med Res Methodol 2020;20:116.

75 Oliver N, Barber JX, Roomp K. The COVID19Impact survey: assessing the pulse of the COVID-19 pandemic in Spain via 24 questions (Preprint). Journal of Medical Internet Research 2020.

76 CDC. Coronavirus Disease 2019 (COVID-19) [Internet]. Centers for Disease Control and Prevention, 2020. Available: https://www.cdc. gov/coronavirus/2019-ncov/prevent-getting-sick/social-distancing. html [Accessed 1 Jul 2020].

77 Instituto Nacional de Estatística. Inquérito Nacional de Saúde 2014 [Internet]. Instituto Nacional de Estatística, 2016. Available: https:// www.ine.pt/xportal/xmain?xpid=INE\&xpgid=ine_publicacoes\& PUBLICACOESpub boui=263714091\&PUBLICACOESmodo=2 [Accessed 17 Nov 2017].

78 Departamento de Salud del Gobierno Vasco. Encuesta de salud de la Comunidad Autónoma del País Vasco (ESCAV), 2017. Available: http://www.euskadi.eus/encuesta-salud/inicio/ [Accessed 17 Nov 2017].

79 Basabe N, Páez D, lerdi X. Calidad de vida, bienestar subjectivo Y salud: inmigración en La CAPV. Ikuspegi. Observatorio Vasco de Inmigración, 2009. Available: http://www.ikuspegi.eus/documentos/ investigacion/es/3ikusgai_salud_inmigracion_ikuspegi.pdf

80 de Luca S, Bobowik M, Basabe N. Adaptación sociocultural de inmigrantes brasileños en El País Vasco: bienestar $Y$ aculturación Rev Psicol Soc 2011;26:275-94.

81 Okafor M-TC, Carter-Pokras OD, Zhan M. Greater dietary acculturation (dietary change) is associated with poorer current selfrated health among African immigrant adults. J Nutr Educ Behav 2014;46:226-35.

82 Stewart A, Marfell-Jones M. International Society for advancement of Kinanthropometry. International standards for anthropometric assessment. Lower Hutt, New Zealand: International Society for the Advancement of Kinanthropometry, 2011.

83 Tanita. TANITA SC-330ST Instruction Manual [Internet]. Tanita Corporation, 2008. Available: https://www.manualslib.com/manual/ 400217/Tanita-Sc-330st.html [Accessed 3 Oct 2018]

84 WHO. Obesity: preventing and managing the global epidemic: report of a who consultation. Geneva: World Health Organization, 2000: 253.

85 Ashwell M, Gibson S. Waist-to-height ratio as an indicator of 'early health risk': simpler and more predictive than using a 'matrix' based on BMI and waist circumference. BMJ Open 2016;6:e010159.

86 Gallagher D, Heymsfield SB, Heo M, et al. Healthy percentage body fat ranges: an approach for developing guidelines based on body mass index. Am J Clin Nutr 2000;72:694-701.

87 Ordem dos Nutricionistas. Código Deontológico da Ordem dos Nutricionistas [Internet], 2016. Available: http://www.ordemdosnutr icionistas.pt/ver.php?cod=0A0O [Accessed 3 Jul 2016].

88 Asociación Espanhola de Dietistas-Nutritionistas. Monográfico Código Deontológico de la profesión de Dietista-Nutricionista (D-N) en España. Nutr Humana Dietética 2018:22:2-8.

89 Agresti A. Categorial data analysis. 2nd edn. Wiley, 2002

90 Lawal B. Categorical data analysis with SAS and SPSS applications. Mahwah, N.J: Lawrence Erlbaum Associates, 2003: 561.

91 Christensen R. Log-Linear models and logistic regression. . 2nd ed. Springer, 1990: 70.113.

92 Marôco J. Análise de Equações Estruturais: Fundamentos teóricos, software \& Aplicações. Report, Lda, 2010: 85.

93 Figueiredo Filho DB. Silva Júnior JA dA. Visão além do alcance: uma introdução análise fatorial. Opinião Pública 2010;16:160-85.

94 Thompson B. Exploratory and confirmatory factor analysis: understanding concepts and applications. 1st ed. Washington, DC: American Psychological Association, 2004: 195.

95 Marôco. Análise Estatística com O SPSS statistics. Pero Pinheiro. Pero Pinheiro, 2011: 309.

96 Hayes AF. Introduction to mediation, moderation, and conditional process analysis: a regression-based approach. 2nd edn. New York: Guilford Press, 2018: 692.

97 Valente MJ, Pelham WE, Smyth $\mathrm{H}$, et al. Confounding in statistical mediation analysis: what it is and how to address it. $J$ Couns Psychol 2017;64:659-71.

98 Howards PP. An overview of confounding. Part 1: the concept and how to address it. Acta Obstet Gynecol Scand 2018;97:394-9.

99 Howards PP. An overview of confounding. Part 2: how to identify it and special situations. Acta Obstet Gynecol Scand 2018:97:400-6.

100 Denzin NK, Lincoln YS, eds. Handbook of qualitative research. Thousand Oaks: Sage Publications, 1994.

101 Galletta A, CROSS WE. Mastering the Semi-Structured interview and beyond: from research design to analysis and publication. NYU press, 2013. Available: https://www.jstor.org/stable/j.ctt9qgh5x [Accessed 9 Oct 2018]

102 Bolderston A. Conducting a research interview. J Med Imaging Radiat Sci 2012;43:66-76.

103 Bardin L. Análise de conteúdo. 70. Lisboa: Edições, 2010.

104 Vaismoradi M, Snelgrove S. Theme in qualitative content analysis and thematic analysis. Forum Qual Soc Res 2019;20.

105 Denzin NK, Lincoln YS. Handbook of qualitative research. Thousand Oaks: Sage Publications, 1994: 643.

106 ATLAS.ti. The Qualitative Data Analysis \& Research Software. atlas. ti. Available: https://atlasti.com/

107 Andrade C. The limitations of online surveys. Indian J Psychol Med 2020;42:575-6.

108 Boni RBD. Websurveys in the time of COVID-19. Cad Saúde Pública 2020:36:e00155820.

109 Bethlehem J. Selection bias in web surveys: selection bias in web surveys. Int Stat Rev 2010;78:161-88.

110 Almeida F. Strategies to perform a mixed methods study. European Journal of Education Studies 2018;5:137-51.

111 Onwuegbuzie A, Leech N. Enhancing the interpretation of significant findings: the role of mixed methods research. Qual Rep 2004;9:770-92

112 Farmer T, Robinson K, Elliott SJ, et al. Developing and implementing a triangulation protocol for qualitative health research. Qual Health Res 2006;16:377-94.

113 O'Cathain A, Murphy E, Nicholl J. Three techniques for integrating data in mixed methods studies. BMJ 2010;341:c4587 